\title{
Development Support Learning Media Based On Android in Subject Operation System
}

\author{
R Rizalita ${ }^{1}$, F Rizal $^{2}$ \\ 1,2Program Studi Pendidikan Teknologi Kejuruan, Universitas Negeri Padang, Indonesia \\ Jl. Prof. Hamka Kampus UNP Air Tawar Padang \\ *Corresponding Author: rafiqarizalita@gmail.com
}

\begin{abstract}
This media designed to increase motivation and creativity of students so that students can understand the overall material provided in the subject operation system. This research used the development metode was $4 D$ (Four $D$ ), while the $4 D$ development procedure those were: define, design, develop, and Disseminate. Data type was primary data where the data provided by the media experts, lecturers and students. Data analysis technique used was descriptive data analysis technique those were describe the validity, practicality and effectiveness of using support learning media.

Results obtained from this development research as follows; (1) The validity of support learning media expressed very valid on the media design with a value of validity was 0.828 , while the materi of media was valid for a value was 0.703 , (2) the practicalities of support learning media based the response of teachers after going through practical trials with a total value was $84.66 \%$, while the practicalities of support learning media based on student response after going through the otherwise very practical trials with a total value of $87.96 \%$.
\end{abstract}

Keywords: development, support learning media, Learning Outcomes

JTIP@Attribution-ShareAlike 4.0 International License

\section{INTRODUCTION}

Educational changes create various educational innovations with the aim of improving the quality of education. Information technology as an innovation has become a necessity for the world of education [1][2]. With the support of technology in the field of education, educators are greatly helped in efforts to improve the quality of learning. One of them is the development of technology with a high level of mobility is smartphone [11]. Mobile technologies purvey opportunities to hold new and interesting methods of teaching and learning [3].

One of the roles of smartphones in education is the use of Android as a learning media. Android is a Linux-based operating system designed for touch screen mobile devices such as smartphones and tablet computers [4]. Android allows users to install third-party applications, with an extensive API that includes access to phone hardware, settings, and user data [5], either obtained from application stores such as Google Play, Amazon Appstore, or by downloading and installing APK files from thirdparty sites. The characteristics of mobile devices that have a high degree of flexibility and portability, it allows students to access material, directions and information related to learning anywhere and anytime [6].

The development of learning support media on basic operating system subjects because the material in these subjects requires a strong understanding. Meanwhile, the teaching and learning process in class is fast and concise due to the limited hours of lessons, so the role of supporting media is needed so that students find it easier to study the material repeatedly. As an operating system based on a Graphical User Interface, Android can be an effective tool for students in learning operating systems. Through Android devices, students can see how the Android operating system works. So it is expected that the development of supporting media for Androidbased learning can meet the needs of students in learning material without limitation of time and place.

The research is focused on developing learning media on Android-based mobile devices that have high mobility. The material developed in mobile learning media is the subject of basic operating systems with the basic competence of installing a GUI-based information system for class $\mathrm{X}$ Computer Network Engineering. The expected 
development result is an application that is installed on an Android-based smartphone which is used as a learning support media. Which will then be assessed the level of validity and practicality of mobile learning media based on the assessment of media experts, material experts, teachers and students of class X Computer Network Engineering.

\section{METHOD}

This research was developed using the R\&D (Research and Development) research method and using the Four-D Thiagarajan model [7], there are development steps as below [8]:

\section{a. Define}

The research implementation begins with the determination stage with the definition and definition of learning conditions. To perform a needs analysis, the process is carried out:

\section{1) Class Observations}

Classroom observation activities are carried out when the teaching and learning process is in progress. Observations were made by looking at the basic operating system learning in class X TKJ students. This aims to determine the problem constraints during the teaching and learning process. What phenomena occur in the field is related to learning basic operating systems. These problems or constraints can come from students and teachers who teach basic operating system subjects. Interviews were conducted with teachers for further learning purposes of the Class X TKJ learning system and student learning outcomes. Interviews with students aimed to see student responses to the learning system operating system for class X TKJ.

2) Syllabus Analysis

Syllabus analysis is to review the existing syllabus at SMK Negeri 1 Sintuk Toboh Gadang, to find out whether the material being taught is in accordance with the expected competencies. So that the learning media developed does not deviate from the learning objectives. Before designing a learning media, the book used as a reference must have been reviewed first. This is done to find out the content of the material, how to present it, practice questions and assignments in accordance with the applicable subject syllabus.

\section{b. Design}

The design of the media begins with compiling the components of the media framework based on the needs analysis that has been done. The next step will be assessed the level of validity and practicality of mobile learning media based on the assessment of media experts, material experts, teachers and students of class $\mathrm{X}$ Computer Network Engineering. At this step an Androidbased application development the preparation of learning materials, videos, and evaluations using Adobe Flash CS 6 software. The homepage is designed to have a link to the main page. On the Main page, there are several links to other pages, namely curriculum pages, materials, exercises, dictionaries. On the curriculum page contains SK and KD subjects. The material page contains materials that will be presented in Android-based learning support media equipped with videos and images, as well as a training page containing practice questions.

\section{c. Develop}

The development stage is the stage to produce a product, which is carried out in steps, namely: (1) expert judgment (validation) followed by revisions, then (2) development trials with practicality testing. The goal is to produce learning media products that have been revised and receive input from experts.

1) Validation

At this stage the Android-based learning support media that have been developed are validated by experts. Validation was carried out on material aspects and Android-based media. Material validation aims to see whether the material contained in the Android-based learning support media that has been designed is in accordance with basic competencies. The validator of this study involved 4 validators consisting of two media experts and two material experts. The criteria for determining validators are experts with a minimum master's degree in accordance with the scope under study.

2) Practicality test

The practicality of the media was tried out to see the level of use of the media. Learning media is said to have high practicality, it is practical, easy to use. At this stage the data was studied using a practicality questionnaire by teachers and students of class X TKJ at SMK Negeri 1 Sintuk Toboh Gadang.

\section{d. Disseminate}

Disseminate is implementing learning media in the teaching and learning process in operating system subjects. This disseminate aims to get input, corrections, suggestions, assessments, to improve the final results of developing Android- 
based learning support media so that they are ready to be adopted by users.

e. Subject

The research subjects in the development of Android-based learning media on the subject of the operating system were class $X$ students of Network Computer Engineering at SMK Negeri 1 Sintuk Toboh Gadang.

\section{f. Data}

The type of data in this research on the development of learning support media based on Android is primary data, meaning that data is directly obtained from the research subject, namely from media experts, learning content experts. The data referred to the results of qualitative research is called descriptive validity [9]. Teachers and students through a questionnaire given the results were analyzed using the Cohen Kappa analysis.

g. Instrument

To obtain the data needed in this study, data collection techniques were used in the form of observation, interviews, questionnaires.

1) Observation

The author's observations during the learning process.

2) Questionnaire

The questionnaire that uses in this study is a closed questionnaire, where the answer is already provided and the respondent is asked to provide information or answers to the statement items that are in accordance with the actual situation. Questionnaire in the form of an attitude scale was used, namely the Likert scale, which is widely used to measure attitudes, perceptions of a person or group of people towards certain phenomena. With Likert scale, the measured variables become variable indicators [10]. There are five alternative answers, namely very suitable, appropriate, inappropriate and unsuitable. The highest score is 5 with the alternative answer is very suitable, and the lowest score is on number 1 with the alternative answer is not suitable.

a) Media and Materials Questionnaire

The material expert instrument contains aspects related to learning media material which includes aspects of learning, material and content truth [12]. The media expert instrument contains points about aspects related to learning media.

b) Teacher and Student Practicality

Quistionnaire
The media practicality questionnaire consists of sheets to measure the practicality of learning media for teachers and students. The results of this practicality were obtained in the form of responses and suggestions from teachers and students who provided assessments [12].

\section{h. Data Analysis}

The data analysis used is descriptive data analysis technique. Namely by describing the validity and practicality of instructional media.

1) Validity Analysis

The validity analysis uses the Cohen Kappa analysis technique based on the validation sheet that has been filled in by the validator. Cohen Kappa analysis is used to measure agreement between two assessors, using a formula :

$$
K K=\frac{P_{0}-P_{\varepsilon}}{1-P_{\varepsilon}}
$$

dengan

$$
P e=\frac{1}{N^{2}} \sum\left(N_{1}\right)\left(N_{2}\right)
$$

Information :

KK : Observation agreement coefficient

PO : Proportion of agreement frequency

Pe : Possible agreement

$\mathrm{N}$ : The total value of observed symptoms

$\mathrm{N} 1$ : The sum of the first category scores for the first observer

$\mathrm{N} 2$ : The sum of the first category scores for the second observer

The criteria used to view the assessment categories can be seen in the Table.

Table 2. Validity Category based on Cohen Kappa Analysis

\begin{tabular}{cc}
\hline Kappa Scale & Category \\
\hline$<0.00$ & Very Weak \\
$0.00-0.20$ & Weak \\
$0.21-0.40$ & Very Simple \\
$\mathbf{0 . 4 1 - 0 . 6 0}$ & Simple \\
$0.61-0.80$ & Valid \\
$\mathbf{0 . 8 1 - 1 . 0 0}$ & Very Valid \\
\hline
\end{tabular}

Source : modification from Zamri Muhammad and Qoriah $\mathrm{Hj}$ Moh Ishak [12]

2) Practicality Analysis

The data analysis used in this practicality assessment is the percentage technique. While the tolls used for data analysis are using Microsoft Office Excel. Practical analysis 
uses a percentage technique based on a validation sheet.

To determine the practicality viewed by the scores of the results of the analysis on practicality by students and teachers are grouped into categories in the Table :

Table 3. Practicality Category

\begin{tabular}{cc}
\hline Tingkat Pencapaian & Kategori Penilaian \\
\hline $81-100$ & Sangat Praktis \\
$61-80$ & Praktis \\
$41-60$ & Cukup Praktis \\
$21-40$ & Kurang Praktis \\
$0-20$ & Tidak Praktis \\
\hline
\end{tabular}

Sumber : Dimodifikasi dari Riduwan [13]

\section{RESULT AND DISCUSSION}

This study produces learning support media for Basic Operating Systems subjects. The development of this media is based on observations of the learning process of the Basic Operating System subject which aims to determine the problems and obstacles in learning, then needs analysis, including curriculum analysis and identification of material needed.

\section{A. Development Process}

This media was developed using the Four-D method which went through several stages, below:

1) Define

Discovery stage to get an overview of conditions in the field. This stage analyzes the need for the process of making learning media. At this stage the following steps are :

a) Observation

The results of observations made at SMK Negeri 1 Sintuk Toboh Gadang found a problem that so far the learning process is teacher centered.The students are passive, only relying on teachers.

b) Curriculum analysis

Curriculum analysis refers to the syllabus of the Basic Operating Systems subject at SMK Negeri 1 Sintuk Toboh Gadang, so the learning media that will be produced does not deviate from the learning objectives.

2) Design

This stage is the design of the media in accordance with the design that has been made. The results of the media design consist of :

a) Homepage Design;

The design of homepage begins with making the background color application that the author chooses is black, then adding writing in the form of media titles, subjects, majors and school levels to explain to whom the learning media is aimed. Finally, the author made the home button which is used as a link to continue to the next page. The link is added with the following ActionScript :

home.addEventListener(MouseEvent.CLICK,fl_ClickTo GoToAndStopAtFrame_65);

functionfl_ClickToGoToAndStopAtFrame_65(event:M ouseEvent):void \{ gotoAndStop(Nomor Frame Halaman Petunjuk);

The resulting opening page is as follows :

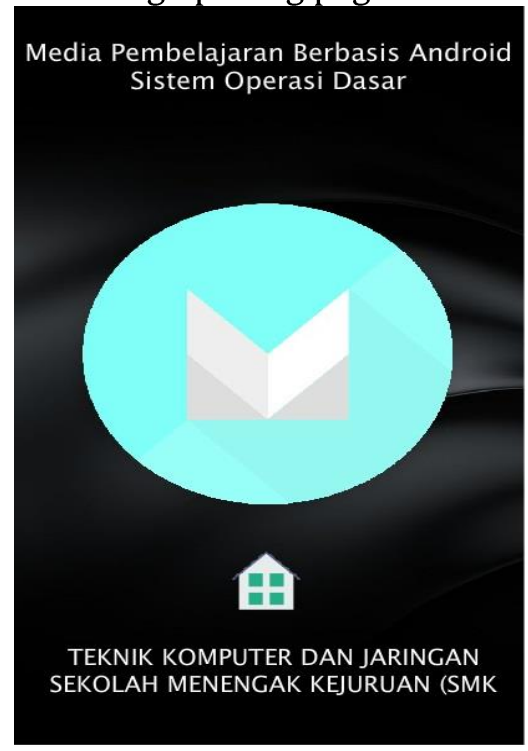

Figure 1 Opening Page

b) Instructions Page;

The instructions page contains an explanation of the instructions for using learning media and the menus available in the application. On this page there is one button, namely the next button to continue to the main menu page.

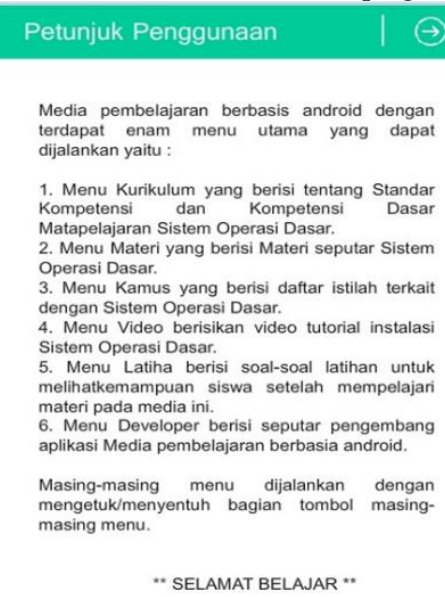

Figure 2 Instructions Page 
c) Main Menu;

Main menu page there are five menus provided in the application, namely: Curriculum menu which contains competency standards and basic competencies for Operating System subjects. Material menu contains material related to basic operating system subjects. Furthermore, the dictionary menu contains a list of terms, the exercise menu to evaluate students who have studied subject in basic operating system applications, and the developer menu which contains the author's bio.

Each menu on this page is added to the existing button design, then adds an ActionScript so that each menu can run to the target page.

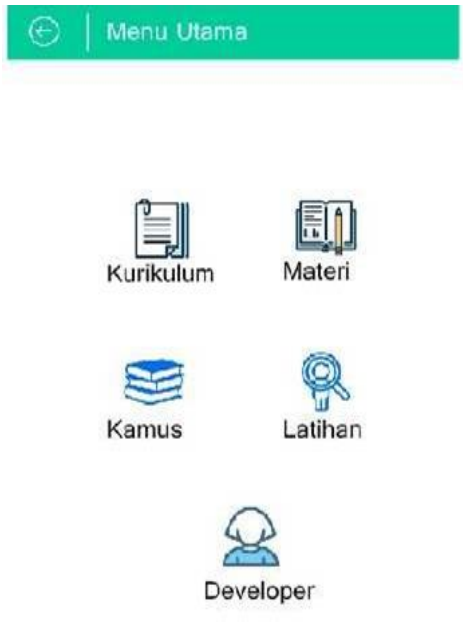

Figure 3 Main Menu

d) Curriculum Page;

The curriculum page contains competency standards and basic competencies, as well as indicators for operating system subjects. To simplify the design, the background used follows the instructions page and the main menu. There is only one button on this page that can be used to return to the main menu page.

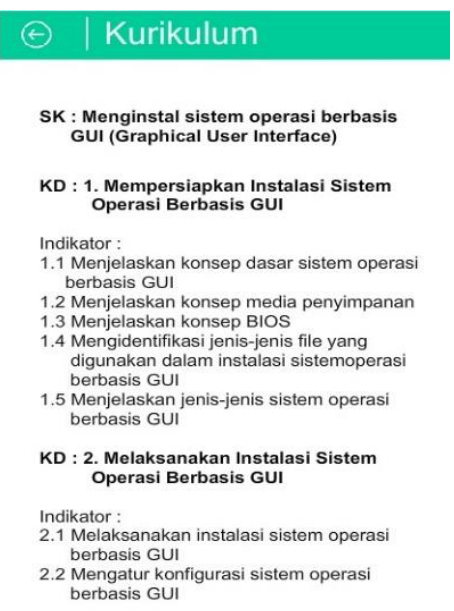

Figure 4 Curriculum Page

e) Material Page;

The material page contains material about operating system learning that is in accordance with curriculum analysis. Each material has a button that links to the intended material page. And in the submaterial presented in this media there is a video link regarding the related material. The videos presented on this page can only be accessed online.

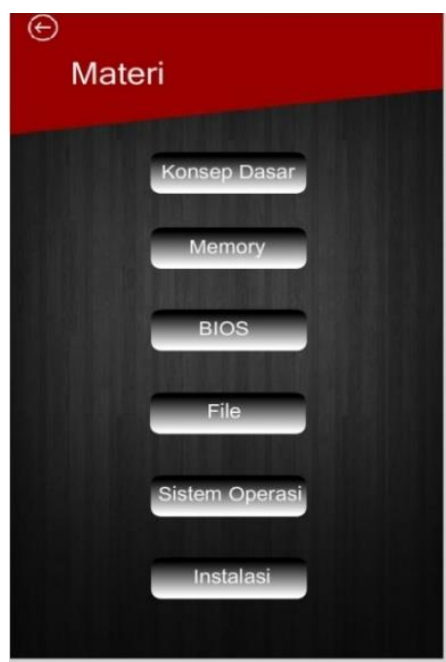

Figure 5 Material Page

Clicking on one of the user material buttons will be linked to the related material page. This page contains the subject and buttons that are used to advance to the next page or return to the previous page. Each button is equipped with an ActionScript as given in the previous explanation. The results of the material page design are as follows : 


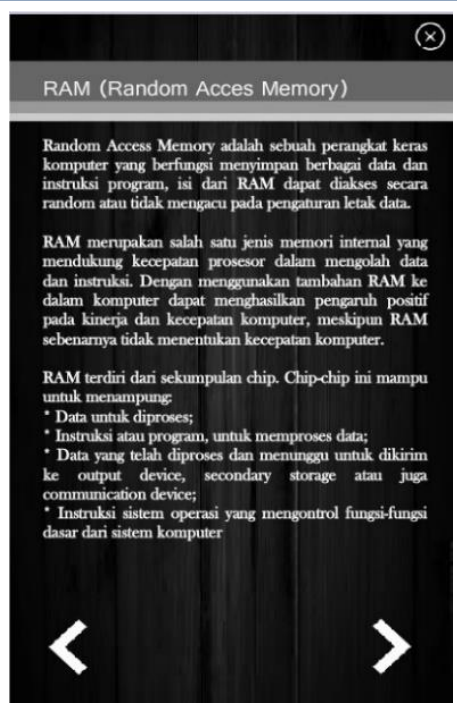

Gambar 6 Material Page

At the end of each lesson the user can see a video tutorial that is played online via the YouTube site. There is a button that connects the user to the website.

\section{f) Dictionary Page;}

The dictionary page design contains difficult and foreign words or terms contained in the learning media with their meanings and arranged alphabetically.

g) Exercise Page;

On this page are also equipped with a manual test execution, and the start button. The start button functions when the user is ready then they can touch the button.

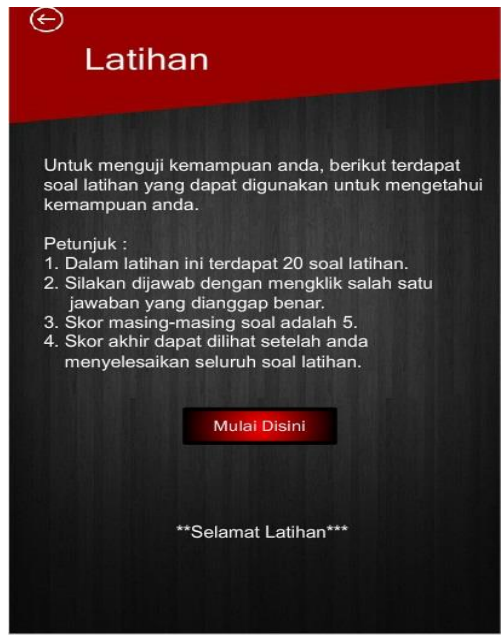

Figure 7 Exercise Menu
The exercise page design contains: practice questions tailored to the material. There are 50 questions in the exam database, but 20 questions are displayed randomly. The Actionscript for random questions is as follows :

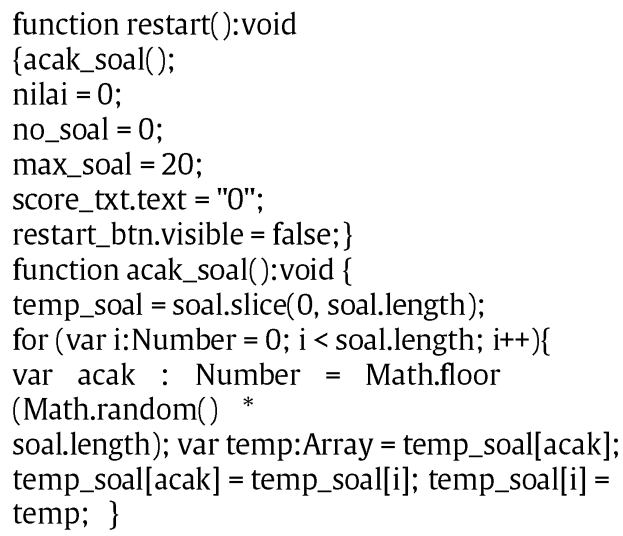

Each correct answer is given a score of 5 , so the maximum score that can be obtained by students is 100 . The ActionScript for calculating the score is as follows:

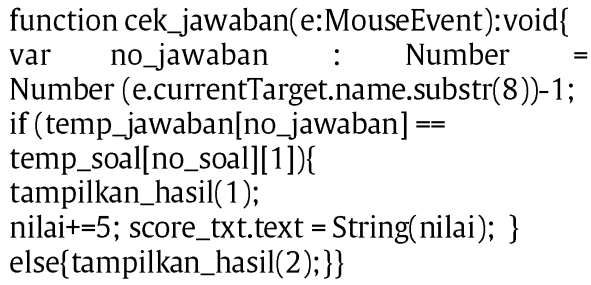

The results of the exercise following page designs :

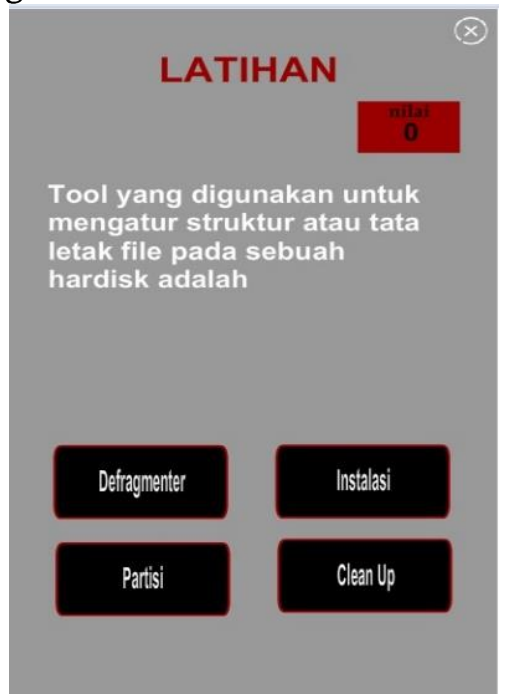

Figure 8 Exercise Page

3) Development

This stage aims to obtain valid, practical, and effective product learning media. This development stage consists of; test the validity of learning media according to the validator's assessment, and practicality test 
according to the assessment of subject teachers and students. The processes from the development stage of the Basic Operating System learning media:

a) Media Validation

The data that will be used to measure the validity of learning media for this Basic Operating System is data obtained through input from the validator using a questionnaire. Before being submitted to the validator, the questionnaire is first validated by the validator to assess the questionnaire given is suitable for use in this study. The media validation stage consists of four validators, each consisting of two media validators and two material validators.

1. Design Validation

The validator validates and assesses the format of the learning media. The media validator assesses the media design from the navigation aspect, the convenience aspect, the written and display aspects.

2. Material Validation

The validator validates and assesses the material. Material validation includes the accuracy of material coverage, conformity between the material and the syllabus.

b) Practicality

1. Teacher Practicality

Practicality relates to the ease of use of the media. The practicality of learning media was obtained from practitioners' responses about the practicality of the media by teachers who taught Basic Operating Systems subjects.

2. Student Practicality

Media practicality was also obtained from students' responses about the practicality of using media. This is to see student responses as users of the developed media.

4) Disseminate

Disseminate via play store. So that this application can be widely used by class X TKJ students who study the Operating System and other who need it.

\section{B. Data Description}

1. Validity test

a) Media Validation Test

Test validity was analyzed by taking the agreement using the formula cohen kappa. Data analysis was performed SPSS 15. From the analysis of data as shown agreement between the indices obtained for 0703 thus supporting media android based learning developed in the category of "Valid" with good results.

b) Material Validation Test

The results of the analysis of the agreement data is 0.828 , it can be concluded that the material presented in the developed subject of the Basic Operating System is "Very Valid" with a good value so that this media can be used as a tool for the learning process.

2. Practicality Test

a) Teacher Response

The average percentage of votes from both practitioners, among others: (1) the technical use of acquired $84 \%$ categorized as very practical, (2) Fill in the time earned $86 \%$ categorized as very practical, (3) the design obtained $84 \%$ categorized as very practical and obtained Overall average is $84.67 \%$ with very practical category. These results indicate that the media developed is "very practical" so that it makes it easier for teachers to help students learn and help students understand the concept of learning material.

Table 4 Teacher Response Data to the Practicality of Learning Media

\begin{tabular}{|c|c|c|c|c|}
\hline \multirow[t]{2}{*}{ Aspect } & \multicolumn{3}{|c|}{ Percentage of Assessment } & \multirow{2}{*}{ Category } \\
\hline & $\mathrm{P} 1$ & $\mathrm{P} 2$ & Rata-rata & \\
\hline Navigation & 84 & 84 & 84 & Very Practical \\
\hline Content & 84 & 88 & 86 & Very Practical \\
\hline Design & 88 & 80 & 84 & Very Practical \\
\hline Average & & & 84,67 & Very Practical \\
\hline
\end{tabular}

P1= Practitioners 1 P2= Practitioners 2

b) Student Response

The average practicality test results of the Basic Operating System learning media according to the students were 87.96 , so it can be concluded that the media was included in the "Very Practical" category to be used as a learning medium. 
Table 5 Student Response Data to the Practicality of Learning

Media

\begin{tabular}{lll}
\hline Aspect & $\begin{array}{l}\text { Percentage of } \\
\text { Assessment }\end{array}$ & Category \\
\hline Convenience & 89.6 & Very Practical \\
Motivation & 86 & Very Practical \\
Attractiveness & 90.5 & Very Practical \\
Usefulness & 85.75 & Very Practical \\
\hline Average & 87.96 & Very Practical \\
\hline
\end{tabular}

\section{CONCLUSION}

The learning support media for the Basic Operating System is stated in the aspect of media design, the aspect of conformity of the material with the curriculum is stated as "valid". Thus, the learning support media for the Basic Operating System is suitable for use as a learning media. The practicality of the media in learning can be seen from the proper use of learning support media for the Basic Operating System as a whole. This can be seen from the practicality of instructional media based on practicality assessments by the teacher which are stated as "very practical" and based on student assessments also stated "very practical".

\section{REFERENCES}

[1] Widyastuti Akhmadan, "Pengembangan Bahan Ajar Materi Garis dan Sudut Menggunakan Macromedia Flash dan Moodle Kelas VII Sekolah Menengah Pertama", Jurnal Gantang, Vol.2, Issue 1, pp.27-40, 2017.

[2] Munir Tanrere, Sumiati Side, "Pengembangan Media Chemo-Edutainmentmelalui Software Macromedia Flash MX pada Pembelajaran IPA Kimia SMP", Jurnal Pendidikan dan Kebudayaan, Vol. 18, Issue 2, pp.156-162, 2012.

[3] Ken Nee Chee, Noraffandy Yahaya, Nor Hasniza Ibrahim, Mohamed Noor Hasan, "Review of Mobile Learning Trends 2010-2015: A MetaAnalysis", Educational Technology \& Society, 20, pp. 113-126, 2017.

[4] Monika Sharma, Ankit Thakur, "Review Paper on Android Operating System", International Journal of Emerging Trends in Science and Technology, Vol.2, Issue 5, pp. 2486-2490, 2015.

[5] Adrienne Porter Felt, Erika Chin, Steve Hanna, et al, "Android permissions demystified", CCS '11: Proceedings of the 18th ACM conference on Computer and communications security, pp. 627-638, October 2011.
[6] Kim Hyo Jung, Lee Jin Myong, Rha Jong Youn, "Understanding the role of user resistance on mobile learning usage among university students", Computer and Education, 113, pp. 108-118, 2017.

[7] Dian Kurniawan, Sinta Verawati Dewi, "Pengembangan Perangkat Pembelajaran dengan Media Screencast O Matic Media Pada Mata KUliah Kalkulus 2 Menggunakan Model 4D Thiagarajan", Jurnal Siliwangi, 3,pp. 214-219, 2017.

[8] Fajar Irsyadul Afkar, Rudi Hartono, "Pengembangan Lembar ajar peserta didik dengan Model Pengembangan 4-D pada Materi Mitigasi Bencana dan Adaptasi Bencana Kelas X SMA", JURNAL PENDIDIKAN GEOGRAFI: Kajian, Teori, dan Praktek dalam Bidang Pendidikan dan Ilmu Geografi, 20, pp. 135-147, 2017.

[9] Sugiyono, Metode Penelitian Kuantitatif Kualitatif dan R\&D, Alfabeta, Bandung, 2013.

[10] R Burke Jhonson, "Examining the validity structure of qualitative research", Education, 118, pp. 282, 1997.

[11] A. Samala, B. Fajri, and F. Ranuharja, "DESAIN DAN IMPLEMENTASI MEDIA PEMBELAJARAN BERBASIS MOBILE LEARNING MENGGUNAKAN MOODLE MOBILE APP", tip, vol. 12, no. 2, pp. 13-20, Dec. 2019.

[12] Azhar Arsyad, Media Pembelajaran, Raja Grafindo Persada, Jakarta, 2011.

[13] Mohamad Z, NM Ishak, "Analisis Cohen Kappa : Dalam Penyelidikan Bahasa : Satu Pengalaman", Seminar Penyelidikan Pendidikan Guru Peringkat Kebangsaan, pp. 1-7, Januari 2003.

[14] Riduwan, Belajar Mudah Penulisan Untuk Guru-Karyawan dan Peneliti Pemula, Alfabeta, Bandung, 2010. 